\title{
15. GEOCHEMISTRY OF BASALTS FROM MESOZOIC PACIFIC OCEAN CRUST: DEEP SEA DRILLING PROJECT LEG $91^{1}$
}

\author{
A. D. Saunders, University of Leicester ${ }^{2}$
}

\begin{abstract}
Basalts recovered from Sites 595 and 596 on Mesozoic crust in the southwest Pacific range from olivine-bearing tholeiites to ferrobasalts. Despite having undergone extensive low-grade alteration, which has raised $\mathrm{K}$ and $\mathrm{Rb}$ abundances, the basalts have consistent interelement ratios of $\mathrm{Ti}, \mathrm{Zr}$, Hf, rare-earth elements, $\mathrm{Y}, \mathrm{Th}, \mathrm{Ta}$, and $\mathrm{Nb} . \mathrm{La} / \mathrm{Ta}(\sim 18), \mathrm{La}_{\mathrm{n}} /$ $\mathrm{Yb}_{\mathrm{n}}(0.6), \mathrm{Ti} / \mathrm{Zr}(115), \mathrm{Zr} / \mathrm{Nb}(20)$, and $\mathrm{Th} / \mathrm{Hf}(0.08)$ ratios all fall within the range of $\mathrm{N}$-type mid-ocean-ridge basalt. The basalts from Sites 595 and 596 indicate that the Mesozoic Pacific crust was derived from a mantle source by processes similar to those operating at the present-day East Pacific Rise.
\end{abstract}

\section{INTRODUCTION}

Much of the ocean crust on the Pacific and Atlantic ocean floors comprises tholeiitic basalts formed at spreading centers. Although far from constant in composition since they range from olivine-rich tholeiites to ferrobasalts, the majority of ocean-ridge basalts are depleted in light rare-earth elements (REE) and other highly incompatible elements, a feature considered to reflect the composition of their mantle source. Most ridge-derived basalts recovered from the eastern Pacific, the East Pacific Rise (EPR), and the Galapagos Spreading Center, are these depleted, or normal (N-type) mid-ocean-ridge basalts (MORB) (Sun et al., 1979; Rhodes et al., 1976; Thompson et al., 1976; Mattey and Muir, 1980; Humphris et al., 1980; Saunders, 1983; Marsh et al., 1983).

Unfortunately, few data are available for pre-Cenozoic Pacific crust, and none for pre-Cretaceous crust. (Material recovered from the Jurassic sequences in the Nauru Basin probably represents off-axis volcanism that may not be typical of the Jurassic ocean basement as a whole; Larson, Schlanger, et al., 1981; Moberly, Schlanger, et al., in press.) This omission has, until the recovery of Mesozoic crust during Leg 91, prevented an objective chemical investigation of ancient Pacific crust; in particular, it has made it impossible to monitor secular variations in crustal accretion processes and mantle evolution.

Leg 91 was the second of two legs primarily dedicated to the placing of a Defense Advanced Research Projects Agency (DARPA) seismometer package into oceanic basement. Following the unsuccessful deployment of a package during Leg 88 in the northeast Pacific, Leg 91 drilled a series of four holes $(595,595 \mathrm{~A}, 595 \mathrm{~B}$, and 596) in the southwest Pacific on old ocean crust near the seismically active Tonga Trench (Fig. 1). The DARPA package was successfully deployed in Hole 595B.

\footnotetext{
${ }^{1}$ Menard, H. W., Natland, J., Jordan, T. H., Orcutt, J. A., et al., Init. Repts. DSDP, 91: Washington (U.S. Govt. Printing Office).

2 Address: Department of Geology, University of Leicester, Leicester LEI 7RH, United
}

Prior to Leg 91, the regional magnetic survey data indicated that the magnetic anomalies in the area of study were either subdued or too confused to resolve. From these data it was thought, however, that the crust at Site 595 formed by rapid spreading in high southern latitudes during Mesozoic times (Montgomery and Johnson, this volume). Studies of the sedimentary rocks recovered during Leg 91 so far have failed to ascertain a precise age for the succession, but a magnetic survey carried out during Leg 91 indicates that the sites possibly are located on Anomaly M29 (see Site 595 report, this volume). This would give a Callovian age of approximately 150 m.y. implying that this may be the oldest oceanic crust so far drilled by Glomar Challenger. In this chapter, I describe these rocks as generally Mesozoic given the lack of biostratigraphic confirmation of the crustal age estimated from magnetic anomalies.

Three of the four holes (595A, 595B, and 596) drilled into basement, although recovery from Hole 596 was minimal. The sequence in Hole 595B, the deepest hole, comprises three lithologic units, ranging from olivine tholeiite to ferrobasalt. The same two uppermost units were recovered in the adjacent Hole 595A. This chapter will present and briefly describe the whole-rock geochemistry of selected basalt samples to assess downhole chemical variations, to compare with basalts erupted at present-day and Cenozoic Pacific spreading centers, and to monitor secular variation in Pacific crust from the Jurassic(?) to the present. Much of the Leg 91 basalt has undergone moderate to intense hydrothermal alteration, so samples were selected from the least-altered portions of the core, wherever possible.

\section{ANALYTICAL TECHNIQUES}

Whole-rock samples $(20-30 \mathrm{~g})$ were washed in deionized water and ground to a fine powder in an agate swing mill. Major elements were determined on glass fusion disks and trace elements on powder briquettes, using a Philips PW1400 X-ray fluorescence spectrometer at Bedford College, University of London. Full details of the analytical technique are given in Saunders (in press).

The REE Th, Hf, and Ta, have been determined for three Leg 91 basalts by instrumental neutron-activation analysis. The techniques used were similar to those described by Saunders (1983).

As with previous studies of DSDP material, every effort has been made to ensure compatibility with data from other legs, in particular, 


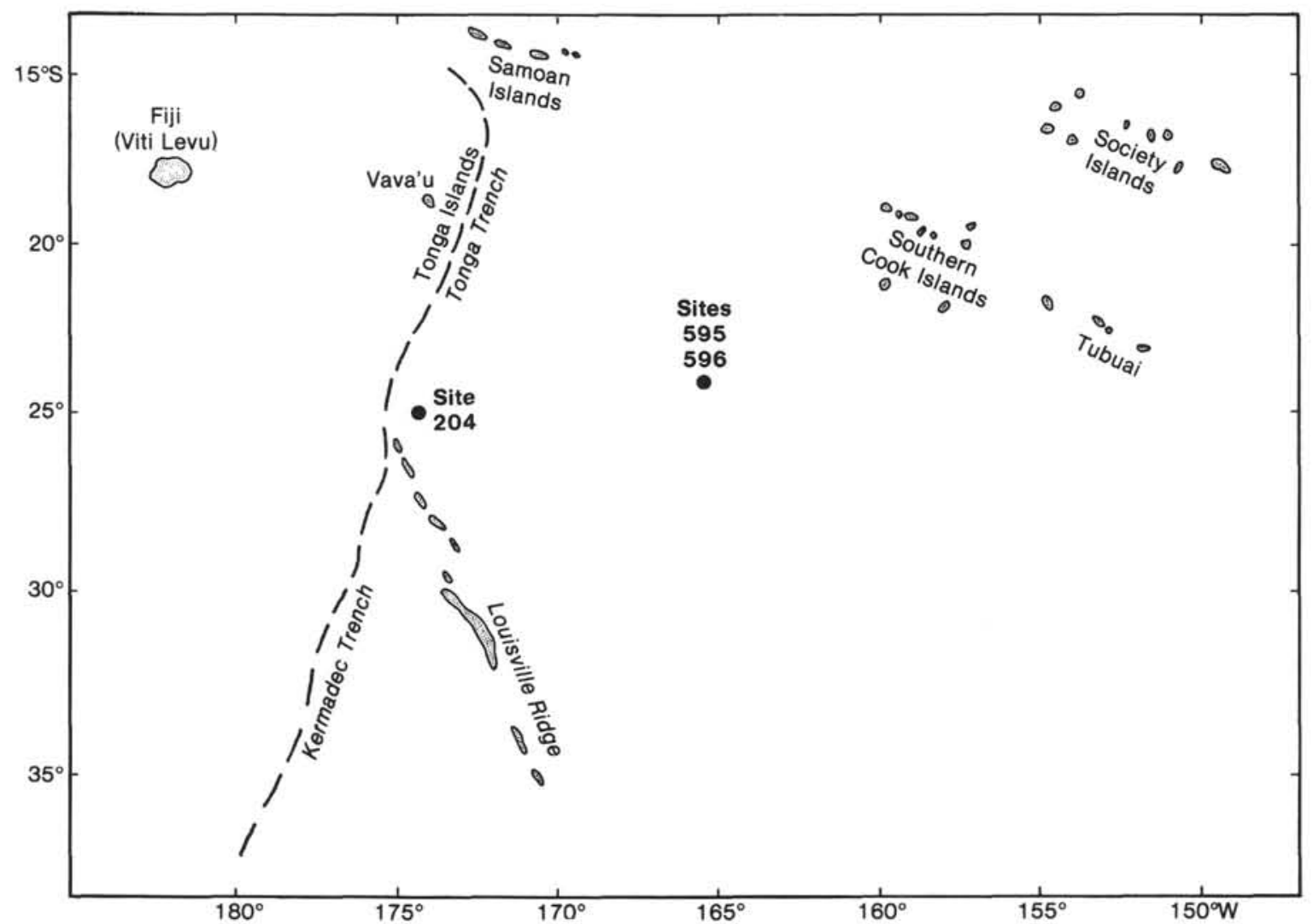

Figure 1. Map of the southwestern Pacific showing location of Sites 595 and 596.

Legs 34 (Nazca Plate), 54 and 65 (EPR and Galapagos Spreading Center, 69 and 70 (Costa Rica Rift), 86 and 88 (northwest Pacific), and 89 (Nauru Basin). Samples from all of these legs have been analyzed at Bedford College using techniques identical to those used during the analysis of the Leg 91 material. Data for reference standard BOB-1 are given in Table 1.

Glass analyses were obtained by Dr. J. Natland, using a Camebax electron microprobe at Scripps Institution of Oceanography. The procedures used are described in Natland et al. (1983), with normalization to U.S.N.M. glass standard VG-2 (cf. Melson et al., 1976). Glasses were recovered from the second and third of the petrographic units described below, but not the first.

\section{LITHOLOGY AND PETROGRAPHY}

\section{Hole 595A}

Located at $23^{\circ} 49.34^{\prime} \mathrm{S}, 165^{\circ} 31.62^{\prime} \mathrm{W}, 5614 \mathrm{~m}$ water depth, this hole penetrated $18.7 \mathrm{~m}$ into basement. On the basis of shipboard descriptions (Site 595 chapter, this volume), the recovered core has been divided into two lithologic units (Fig. 2).

Unit 595A-1 (3.8 m recovered) is a gray-brown basalt, with numerous fine-grained to glassy selvages that represent the chilled margins of either pillows or thin sheet flows. Most of the samples are fine to medium grained, with basaltic mineralogy of plagioclase and interstitial clinopyroxene. No olivine was reported from the thin sections studied, implying that the basalt is moderately evolved. Scarce plagioclase microphenocrysts are also present, and the basalt is slightly vesicular. It is moderately to severely altered, with clay mineral and iron oxyhydroxide alteration products. This unit was initially termed an andesite from shipboard observations, but the $\mathrm{SiO}_{2}$ content and olivine-normative chemistry (Table 2) shows that it is a normal tholeiite.

Unit 595A-2 (5.4 m recovered, base not seen) is a dark gray, fine-grained, sparsely phyric basalt with glassy to microlitic textures. The frequent, curved, glassy selvages suggest a pillow-basalt morphology. The mineralogy comprises plagioclase, clinopyroxene, titanomagnetite, and glass (the latter now completely replaced by clay minerals) with rare plagioclase and clinopyroxene phenocrysts. No olivine is seen, and the rock is nonvesicular. Again, alteration is pervasive, and the rock is highly fractured. Unit 595A-2 has been termed a tholeiitic ferrobasalt by shipboard petrologists on the basis of (1) absence of olivine, (2) abundance of titanomagnetite, (3) scarcity of plagioclase and clinopyroxene phenocrysts, and (4) presence of a dark, iron-rich spherulite zone within about $1 \mathrm{~cm}$ of the glassy margin. The high iron content of these basalts $\left(14.8-15.7 \%\right.$ total $\mathrm{Fe}_{2} \mathrm{O}_{3}$ ) corroborates the petrographic observations.

\section{Hole 595B}

Located at $23^{\circ} 49.34^{\prime} \mathrm{S}, 165^{\circ} 31.61^{\prime} \mathrm{W}, 5615 \mathrm{~m}$ water depth, this hole penetrated $55 \mathrm{~m}$ into basement. The recovered core has been divided into three units (Fig. 2).

Unit 595B-1 (two small cobbles from Sample 595B$1, \mathrm{CC}$, and the topmost part of Core 595B-2) is petrographically identical to Unit 595A-1. The chemical correlation between the two units could not be confirmed because insufficient material was provided for analysis. 
Table 1. Comparative minor and trace element data for ocean floor basalt BOB-1.

\begin{tabular}{lcc}
\hline \multicolumn{3}{c}{ X-ray fluorescence data } \\
& 1 & 2 \\
\hline & 1.33 & 1.33 \\
$\mathrm{TiO}_{2}$ & 1.38 & 0.37 \\
$\mathrm{~K}_{2} \mathrm{O}$ & 0.38 & 0.16 \\
$\mathrm{P}_{2} \mathrm{O}_{5}$ & 0.13 & 125 \\
$\mathrm{Ni}$ & 107 & 125 \\
$\mathrm{Cr}$ & 236 & 302 \\
$\mathrm{Rb}$ & 4.7 & 6 \\
$\mathrm{Sr}$ & 199 & 188 \\
$\mathrm{Ba}$ & 57 & 55 \\
$\mathrm{Y}$ & 26 & 27 \\
$\mathrm{Zr}$ & 102 & 97 \\
$\mathrm{Nb}$ & 5 & 6 \\
\hline
\end{tabular}

\begin{tabular}{ccc}
\multicolumn{3}{c}{ INAA data } \\
& 3 & 4 \\
\hline $\mathrm{La}$ & 4.7 & 4.6 \\
$\mathrm{Ce}$ & 13.8 & 14.5 \\
$\mathrm{Nd}$ & 10.7 & 10.2 \\
$\mathrm{Sm}$ & 3.3 & 3.0 \\
$\mathrm{Eu}$ & 1.25 & 1.20 \\
$\mathrm{Gd}$ & 4.16 & 4.10 \\
$\mathrm{~Tb}$ & 0.74 & 0.72 \\
$\mathrm{Tm}$ & 0.41 & - \\
$\mathrm{Yb}$ & 2.63 & 2.53 \\
$\mathrm{Lu}$ & 0.44 & 0.45 \\
$\mathrm{Ta}$ & 0.51 & 0.48 \\
$\mathrm{Th}$ & 0.45 & 0.42 \\
$\mathrm{Hf}$ & 2.53 & 2.56 \\
\hline
\end{tabular}

Note: Column 1 = Saunders (1983); Column $2=$ this study and Saunders (in press); Column 3 = average of eight determinations (1981-1983); Column $4=$ this study and Saunders (in press); $-=$ not analyzed.

Unit 595B-2 (13.7 m of basalt recovered from a cored interval of $42.2 \mathrm{~m}$ ) is petrographically (and chemically) similar to Unit 595A-2.

Unit 595B-3 (2.7 m recovered, base not seen) is a dark gray, essentially aphyric basalt with a fine-grained variolitic texture. As in Hole 595A, chilled margins again indicate that the basalt was erupted as pillows rather than sheet flows. It is distinct from the basalt of Units 595B-1 and 2 in that it contains rare olivine microphenocrysts (now completely altered) and olivine dendrites in spherulites. The presence of modal olivine concurs with the chemistry of this unit; it is less evolved than Unit 595-2 (e.g., Fig. 2).

An interesting feature of this basalt is the distinct mottled effect seen on cut surfaces and apparent in thin sections as an uneven distribution of iron oxides. This is ascribed to the mottling to local mixing between Fe-rich and Fe-poor magmas (see Site 595 chapter, this volume). It is perhaps noteworthy that chemically Unit 595B-3 occupies a stage intermediate between Units 595B-1 and 2.

Again, as with the other basalts from Site 595, the material from Unit 595B-3 has undergone pervasive secondary alteration.

\section{Hole 596}

Located at $23^{\circ} 51.20^{\prime} \mathrm{S}, 165^{\circ} 39.27^{\prime} \mathrm{W}, 5701 \mathrm{~m}$ water depth, Hole 596 is approximately $8 \mathrm{~km}$ west of Hole 595B. Basement was penetrated to a total depth of $5.6 \mathrm{~m}$ using the extended core barrel, but recovery was very poor, restricted to only a few chips of basalt, which is aphyric, sparsely vesicular, and rich in secondary iron oxyhydroxides.

\section{CHEMISTRY}

\section{Site $\mathbf{5 9 5}$}

The chemistry of the Site 595 basalts will be described on a unit-by-unit basis, because there is a clear petrographic and geochemical correlation between Units 595A-2 and 595B-2 (Fig. 2 and Tables 2 and 3).

\section{Unit 595A-1}

Unit 1 comprises olivine-normative tholeiite with $6.8 \%$ $\mathrm{MgO}$ and an $\mathrm{Mg}$ number $(100 \mathrm{Mg} / \mathrm{Mg}+\mathrm{Fe})$ of 56 . Although these values are higher than in the basalts from Units 2 and 3, showing that Unit 1 is the least fractionated of the three units, they indicate that it cannot represent a primary melt derived from spinel lherzolite mantle. Similarity, the moderate $\mathrm{Ni}(60-97 \mathrm{ppm})$ and $\mathrm{Cr}$ (202-209 ppm) abundances demonstrate that olivine and pyroxene fractionation occurred prior to eruption; hypothetical primary melts contain at least $200 \mathrm{ppm} \mathrm{Ni}$ (e.g., Kay et al., 1970).

The immobile trace and minor elements $(\mathrm{Ti}, \mathrm{P}, \mathrm{Zr}$, $\mathrm{Nb}, \mathrm{Ni}, \mathrm{Cr}, \mathrm{Y}, \mathrm{REE}, \mathrm{Th}, \mathrm{Hf}$, and $\mathrm{Ta}$ ) show a limited range of values; for example, $\mathrm{Zr}$ ranges from 83 to 87 $\mathrm{ppm}$, indicating production of this unit from a single effusion of magma. The absolute abundances of all of these elements are within the range of N-type MORB recovered from the EPR, Nazca Plate, and Mid-Atlantic Ridge (MAR). More significant, however, is the close comparison of incompatible element ratios between the Leg 91 basalts and N-type MORB, for example, $\mathrm{Ti} / \mathrm{Zr}$ ( 115, Fig. 3), $\mathrm{Zr} / \mathrm{Nb}(\sim 30), \mathrm{La}_{\mathrm{n}} / \mathrm{Yb}_{\mathrm{n}}(\sim 0.6$, Fig. 4$)$, $\mathrm{La} / \mathrm{Ta}$ (18, Fig. 5), and Th/Hf (0.08, Fig. 6) ratios.

One sample from Unit 595A-1 has been analyzed for REE, Ta, Th, and Hf (Table 4). Despite the possibility of REE mobility during intense alteration (Ludden and Thompson, 1978; Humphris, 1984), I consider that the strong light REE depletion observed in Sample 595A-10-1, $103-107 \mathrm{~cm}$ (Fig. 4) is a primary characteristic, because the REE patterns for all of the Leg 91 basalts are parallel. Mobilization during secondary alteration would be expected to lead to nonparallel patterns.

The alkaline elements $\mathrm{K}$ and $\mathrm{Rb}$ tend to have abundances much higher than N-type MORB (normally less than $0.2 \% \mathrm{~K}_{2} \mathrm{O}$ and $2 \mathrm{ppm} \mathrm{Rb:} \mathrm{Hart,} \mathrm{1971;} \mathrm{Sun} \mathrm{et} \mathrm{al.,}$ 1979), but the poor correlation with the so-called immobile elements (e.g., Zr, Fig. 2) suggests that $\mathrm{K}$ and $\mathrm{Rb}$ have been affected by secondary processes (cf. Hart et al., 1974). $\mathrm{Ba}$ and $\mathrm{Sr}$, elements that have variable susceptibility to seawater interaction, have more constant abundances (Table 3 ) and have levels similar to those seen in N-type MORB. Moreover, there is a broad, sym- 


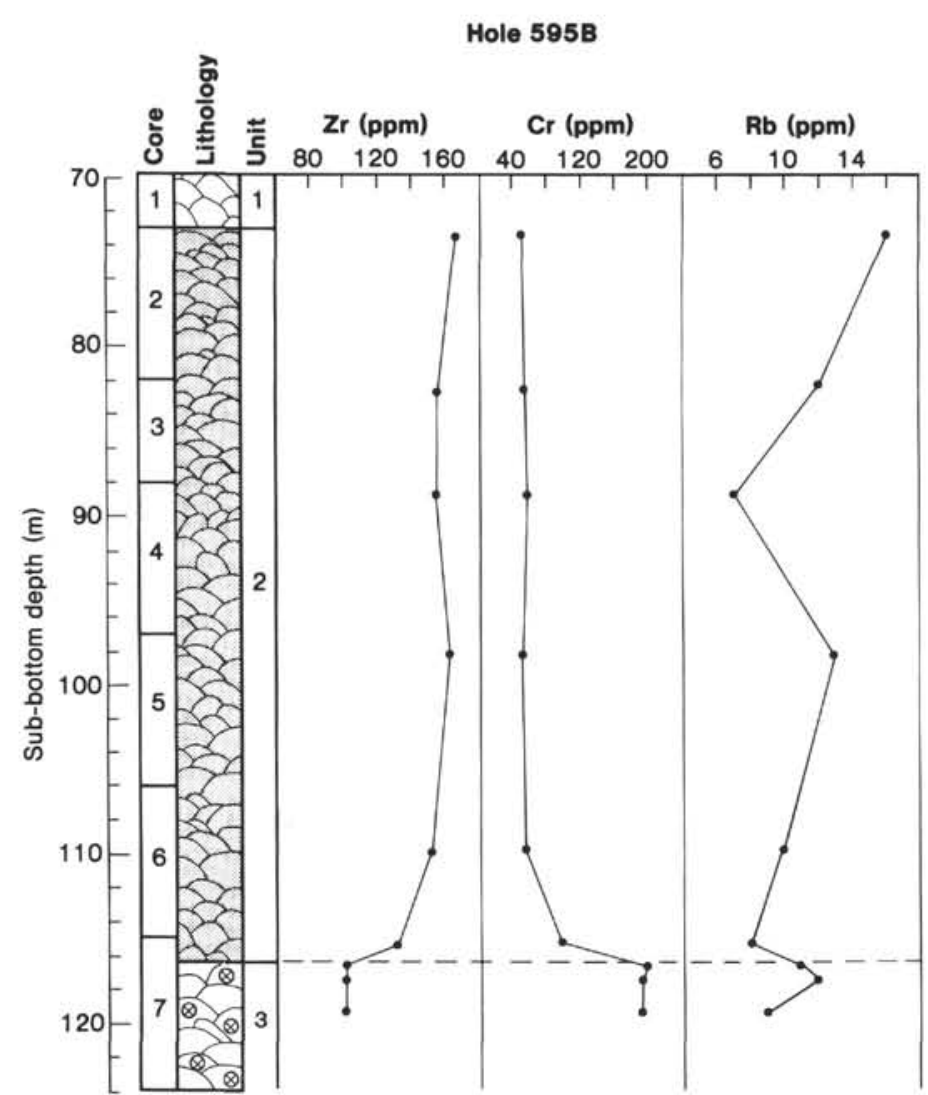

Figure 2. Downhole variations in lithology and geochemistry at Site 595.

pathetic correlation between $\mathrm{Ba}$ and $\mathrm{Zr}$, at least within the Leg 91 basalts as a whole, implying that the $\mathrm{Ba}$ levels may be primary (Fig. 7). This concurs with previous studies that have suggested that during low-temperature hydrothermal alteration, Ba may not be very mobile (Hart et al., 1974).

\section{Units 595A-2 and 595-2}

These analyses will be treated as a single unit. All of the basalts are olivine-normative tholeiites, but are more evolved than Unit $595 \mathrm{~A}-1$. This is illustrated by the high iron content (total $\mathrm{Fe}_{2} \mathrm{O}_{3}, 13-16 \%$ ) low $\mathrm{MgO}(5.8-6.3 \%$ ), $\mathrm{Ni}$, and $\mathrm{Cr}$, and high incompatible element contents $(\mathrm{Zr}$, 152-166 ppm) (Tables 2 and 3). In terms of Fe, Ti, Zr, and $P$ contents these basalts are similar to ferrobasalts from the Nazca Plate and Galapagos Spreading Center (Table 5) although they have unusually low $\mathrm{CaO}$ contents. Like the Nazca Plate basalts, they differ from the Galapagos basalts in having higher $\mathrm{Ti} / \mathrm{Fe}$ ratios (cf. Natland, 1980).

Incompatible trace element ratios are close to those seen in Unit 1 (Fig. 3-7) and are within the range of $\mathrm{N}$-type MORB. Absolute abundances are similar to those found in ferrobasalts from the Nazca Plate and elsewhere (see Table 5).

As with Unit 595A-1, there is no correlation between $\mathrm{K}$ and $\mathrm{Rb}$ and other incompatible elements so it is assumed that these elements have been affected by secondary alteration.
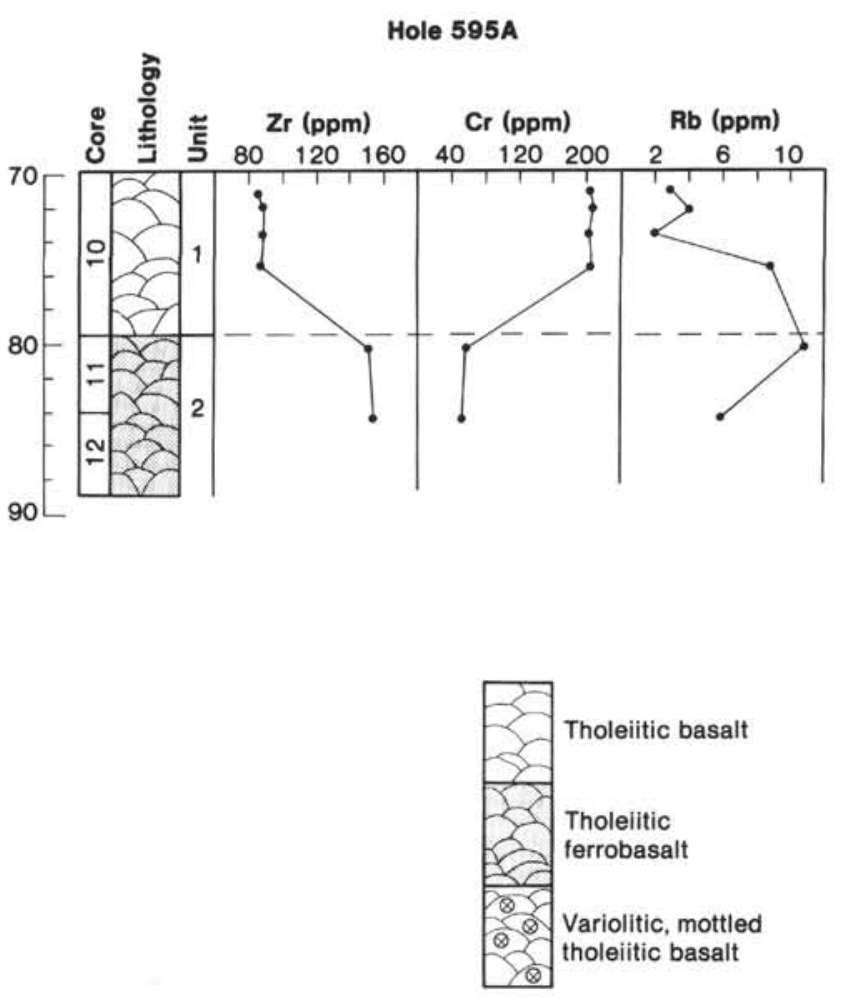

\section{Unit 595B-3}

Two samples from Unit 3 have been analyzed for major elements. Both are olivine-normative tholeiites close in composition to, but slightly more fractionated than, Unit 595A-1.

Therefore, they occupy a compositional location intermediate between the basalts of Units 1 and 2 (Table 2). As with Unit 595A-1, the basalts show a restricted compositional range, implying that the sample interval represents a single eruptive episode.

Incompatible element ratios are similar to those measured in Units 595A-1 and 2, and are well within the range of N-type MORB (Figs. 3-7, Tables 3 and 4).

\section{Site $\mathbf{5 9 6}$}

Only one sample from this site has been analyzed (Tables 2 and 3). The low $\mathrm{SiO}_{2}(47.7 \%)$ has resulted in a nepheline-normative chemistry, atypical of $\mathrm{N}$-type MORB, although the extent to which this is caused by secondary processes is not clear. It should be noted that this basalt contains considerable $\mathrm{CaO}$, suggesting the presence of secondary carbonate, and it has a low oxide total, implying significant contents of $\mathrm{H}_{2} \mathrm{O}$ or $\mathrm{CO}_{2}$. No thin sections have been studied by the author to confirm the presence of calcite, although the rock appears altered in hand specimen and has minor calcite veins (see Site 596 chapter, this volume). 
Table 2. Major element analyses of representative Leg 91 basalts.

\begin{tabular}{|c|c|c|c|c|c|c|c|c|}
\hline \multirow[b]{3}{*}{ Major elements } & \multicolumn{3}{|c|}{ Hole 595A } & \multicolumn{4}{|c|}{ Hole 595B } & \multirow{2}{*}{$\frac{\text { Hole } 596}{9-1,81-83}$} \\
\hline & $10-4,76-80^{\mathrm{a}}$ & $11-1,117-121$ & $12-1,51$ & $2-1,112-116$ & $4-1,12-15$ & $7-1,123-128$ & $7-2,80-82$ & \\
\hline & $1^{b}$ & 2 & 2 & 2 & 2 & 3 & 3 & \\
\hline $\mathrm{SiO}_{2}$ & 50.1 & 48.4 & 49.0 & 48.9 & 49.3 & 49.5 & 49.8 & 47.7 \\
\hline $\mathrm{TiO}_{2}$ & 1.63 & 2.77 & 2.77 & 2.94 & 2.86 & 1.92 & 1.86 & 1.49 \\
\hline $\mathrm{Al}_{2} \mathrm{O}_{3}$ & 14.5 & 13.8 & 13.8 & 14.8 & 14.5 & 14.9 & 14.5 & 15.6 \\
\hline $\mathrm{Fe}_{2} \mathrm{O}_{3}$ & 1.41 & 1.87 & 1.76 & 1.61 & 1.54 & 1.43 & 1.45 & 1.17 \\
\hline $\mathrm{FeO}$ & 9.37 & 12.47 & 11.74 & 10.71 & 10.29 & 9.51 & 9.66 & 7.80 \\
\hline $\mathrm{MnO}$ & 0.18 & 0.23 & 0.28 & 0.15 & 0.20 & 0.20 & 0.24 & 0.16 \\
\hline $\mathrm{MgO}$ & 6.83 & 5.83 & 6.00 & 5.92 & 6.33 & 6.25 & 6.64 & 4.84 \\
\hline $\mathrm{CaO}$ & 11.80 & 8.99 & 9.11 & 7.77 & 8.86 & 11.17 & 10.80 & 14.18 \\
\hline $\mathrm{Na}_{2} \mathrm{O}$ & 2.62 & 2.96 & 3.08 & 3.31 & 3.35 & 2.76 & 2.89 & 2.91 \\
\hline $\mathrm{K}_{2} \mathrm{O}$ & 0.48 & 0.80 & 0.51 & 0.92 & 0.57 & 0.59 & 0.71 & 0.64 \\
\hline $\mathrm{P}_{2} \mathrm{O}_{5}$ & 0.11 & 0.23 & 0.16 & 0.20 & 0.20 & 0.14 & 0.15 & 0.13 \\
\hline Total & 99.03 & 98.35 & 98.21 & 97.23 & 98.00 & 98.37 & 98.70 & 96.62 \\
\hline Mg no. & 56.5 & 45.4 & 47.7 & 49.6 & 52.3 & 53.9 & 55.1 & 52.5 \\
\hline \multicolumn{9}{|l|}{ CIPW norms } \\
\hline $\mathrm{Qz}$ & 0.0 & 0.0 & 0.0 & 0.0 & 0.0 & 0.0 & 0.0 & 0.0 \\
\hline Or & 3.0 & 4.8 & 3.5 & 5.9 & 3.7 & 3.7 & 4.3 & 4.3 \\
\hline $\mathrm{Ab}$ & 22.4 & 25.5 & 26.5 & 28.8 & 28.9 & 23.7 & 24.8 & 17.5 \\
\hline An & 26.5 & 22.3 & 22.5 & 23.2 & 23.1 & 26.9 & 24.8 & 28.3 \\
\hline $\mathrm{Ne}$ & 0.0 & 0.0 & 0.0 & 0.0 & 0.0 & 0.0 & 0.0 & 4.3 \\
\hline Di & 26.2 & 17.9 & 18.3 & 12.1 & 16.7 & 23.5 & 23.5 & 36.1 \\
\hline Hy & 11.9 & 13.9 & 15.8 & 15.3 & 13.4 & 11.0 & 9.3 & 0.0 \\
\hline Ol & 4.6 & 7.0 & 4.9 & 5.9 & 5.8 & 5.0 & 7.3 & 4.5 \\
\hline $\mathrm{Mt}$ & 2.1 & 2.8 & 2.6 & 2.4 & 2.3 & 2.1 & 2.1 & 1.8 \\
\hline $\mathrm{Ilm}$ & 3.1 & 5.3 & 5.3 & 5.7 & 5.5 & 3.7 & 3.6 & 2.9 \\
\hline $\mathrm{Hm}$ & 0.0 & 0.0 & 0.0 & 0.0 & 0.0 & 0.0 & 0.0 & 0.0 \\
\hline Ap & 0.3 & 0.6 & 0.5 & 0.6 & 0.5 & 0.3 & 0.4 & 0.3 \\
\hline D.I. & 25.4 & 30.3 & 30.0 & 34.7 & 32.6 & 27.4 & 29.0 & 26.1 \\
\hline
\end{tabular}

Note: $\mathrm{Fe}_{2} \mathrm{O}_{3}, \mathrm{FeO}, \mathrm{Mg}$ No. $\left(100 \mathrm{Mg} / \mathrm{Mg}+\mathrm{Fe}\right.$ ), and CIPW norms calculated with an assumed $\mathrm{Fe}_{2} \mathrm{O}_{3} / \mathrm{FeO}$ ratio of 0.15 .

a Core-Section (interval in $\mathrm{cm}$ ).

b Unit no.

D.I. = normative $(\mathrm{Qz}+\mathrm{Or}+\mathrm{Ab}+\mathrm{Ne})$.

In terms of $\mathrm{MgO}$ content the basalt is more evolved than those from Site 595, but total iron and incompatible element abundances are lower than in the Site 595 basalts. Absolute abundances and ratios of the immobile trace elements are, however, within the range of $\mathrm{N}$-type MORB. $\mathrm{K}_{2} \mathrm{O}$ and $\mathrm{Rb}$ are much higher than in $\mathrm{N}$-type MORB, but it is likely that their abundances have been enhanced by secondary alteration.

\section{Glasses}

Glass analyses for samples from Unit 2 of Holes 595A and 595B, and Unit 3 of Hole 595B, are listed in Table 6 . Two samples from each unit were analyzed, and their averages are listed in the table, inasmuch as no differences beyond analytical precision were detected within each unit.

The analyses confirm the distinctive iron enrichment of Unit 2 basalts, and the similarity of the Site 595 lava compositions to those of modern eastern Pacific basalts. Unit 3 glasses, in fact, are compositionally identical (to within analytical precision) to standard VG-2 (also listed in Table 6), which is from the Juan de Fuca Ridge.

\section{DISCUSSION}

\section{Interunit Variation}

The absence of suitable phenocrysts in the Site 595 basalts precludes the use of quantitative least-squares mix- ing to calculate the relationship between Units 595B-1, 2 , and 3. Nonetheless it is possible, using trace elements, to place some constraints on the nature of fractionation involved in the generation of the Unit 595B-2 ferrobasalts.

The first question is whether or not the ferrobasalts can be derived from the Unit 595B-3 tholeiites by simple, closed-system Rayleigh fractionation. Low partitioncoefficient elements $\mathrm{Zr}, \mathrm{Hf}, \mathrm{Ta}$, and $\mathrm{La}$ indicate that 39 , 40,41 , and $44 \%$ fractionation, respectively, is required to generate Unit 595B-2 from Unit 595B-3 basalt (i.e., Sample 595B-2-1, 112-116 cm from Sample 595B-7-2, $90-92 \mathrm{~cm}$ ), assuming for the moment that the units represent a comagmatic suite. This is in broad agreement with previous studies of ferrobasalt formation, for example, those from the Galapagos Spreading Center (Mattey and Muir, 1980). Further constraints can be applied by considering $\mathrm{Ni}$ abundances, which decrease from $80 \mathrm{ppm}$ in Unit 595B-3, to some $45 \mathrm{ppm}$ in the most evolved ferrobasalt of Unit 595B-2 (Fig. 8). Nickel is strongly partitioned into olivine and to a lesser extent into pyroxene, and because fractional crystallization tends to rapidly remove high partition-coefficient elements from the melt, it is possible to estimate an upper limit for the bulk distribution coefficient $(D)$ of the crystallizing phases. Assuming $40 \%$ removal of solids, $D_{\mathrm{Ni}}$ cannot greatly exceed 2.5 (Fig. 8), which means that the crystallizing assemblage is dominated by clinopyroxene and plagioclase, with only minor olivine. 
Table 3. Minor and trace element data, Leg 91 basalts.

\begin{tabular}{|c|c|c|c|c|c|c|c|}
\hline \multirow{3}{*}{$\begin{array}{l}\text { Minor and } \\
\text { trace elements }\end{array}$} & \multicolumn{6}{|c|}{ Hole 595A } & \multirow{2}{*}{$\frac{\text { Hole 595B }}{2-1,112-116}$} \\
\hline & $10-1,103-107^{a}$ & $10-2,21-24$ & $10-3,57-60$ & $10-4,76-80$ & $11-1,117-121$ & $12-1,51-54$ & \\
\hline & $1^{\mathrm{b}}$ & 1 & 1 & 1 & 2 & 2 & 2 \\
\hline $\mathrm{TiO}_{2}$ & - & 1.81 & 1.81 & 1.63 & 2.77 & 2.77 & 2.94 \\
\hline $\mathrm{K}_{2} \mathrm{O}$ & - & 0.24 & 0.26 & 0.48 & 0.80 & 0.51 & 0.92 \\
\hline $\mathrm{P}_{2} \mathrm{O}_{5}$ & - & 0.15 & 0.14 & 0.11 & 0.23 & 0.16 & 0.20 \\
\hline $\mathrm{Ni}$ & 78 & 73 & 97 & 60 & 36 & 41 & 46 \\
\hline $\mathrm{Cr}$ & 209 & 209 & 202 & 204 & 59 & 55 & 50 \\
\hline $\mathrm{Rb}$ & 3 & 4 & 2 & 9 & 11 & 6 & 16 \\
\hline $\mathrm{Sr}$ & 107 & 108 & 108 & 105 & 106 & 110 & 118 \\
\hline $\mathrm{Ba}$ & 19 & 19 & 24 & 23 & 24 & 33 & 49 \\
\hline $\mathbf{Y}$ & 35 & 37 & 36 & 32 & 56 & 55 & 54 \\
\hline $\mathrm{Zr}$ & 86 & 87 & 87 & 83 & 152 & 154 & 166 \\
\hline $\mathrm{Nb}$ & 3 & 3 & 3 & 3 & 5 & 6 & 6 \\
\hline $\mathrm{Zr} / \mathrm{Nb}$ & 29 & 29 & 29 & 28 & 30 & 26 & 28 \\
\hline $\mathrm{Ti} / \mathrm{Zr}$ & - & 125 & 125 & 118 & 109 & 108 & 106 \\
\hline $\mathrm{Zr} / \mathrm{Y}$ & 2.5 & 2.4 & 2.4 & 2.6 & 2.7 & 2.8 & 3.1 \\
\hline $\mathrm{P} / \mathrm{Zr}$ & - & 7.5 & 7.0 & 5.8 & 6.6 & 4.5 & 5.3 \\
\hline
\end{tabular}

Note: Oxides in wt. \%, elements in ppm. $-=$ not analyzed.

a Core-Section (interval in $\mathrm{cm}$ ).

b Unit no.

We can test for pyroxene fractionation by considering the distribution of REE and Y. The heavy REE and Y tend to partition into clinopyroxene with greater ease than do the light REE (see review by Irving, 1978), so pyroxene fractionation would be expected to result in increased light REE/heavy REE ratios. This is indeed the case (Fig. 9) since $\mathrm{La} / \mathrm{Yb}$ and $\mathrm{Zr} / \mathrm{Y}$ ratios both increase in the more evolved melts. However, the general absence of clinopyroxene phenocrysts in the Site 595 basalts means that fractionation may have happened at higher pressures, perhaps at the 9-kbar cotectic (Thompson, 1982; Fujii and Bougault, 1983).

Qualitative major element modeling does not, however, agree with the trace element data. The degree of fractionation involved in generating the most evolved Unit 595B-2 ferrobasalt from the most primitive Unit 595B-3 tholeiite is, on major element grounds, significantly less than the $40 \%$ predicted by the trace elements. This apparent decoupling of major and trace elements cannot be satisfactorily modeled by closed-system fractionation, and we must resort to open-system fractionation. In this model, the evolving magma chamber is periodically replenished by a new batch of primitive magma and is episodically tapped to produce eruptives (O'Hara, 1977; O'Hara and Mathews, 1981). One important result of open-system fractionation is that the major element composition of the melt is buffered against the crystallizing phases. However, depending on the size of the magma body, the rate of replenishment, and the degree of fractionation, the incompatible element content of the extracted melt can be increased to an extent far greater than that predicted by closed-system fractionation.

As pointed out by Mattey and Muir (1980), it is unlikely that a magma chamber of sufficient size and duration to produce highly evolved ferrobasalt could remain a simple closed system, although Natland (1980) has suggested that ferrobasalt could form in subsidiary chambers semi-isolated from the main magma body. Critical to all of these arguments are (1) the composition of the primitive, replenishing magma batch; (2) the size of the magma body; (3) the residence time of the magma in the chamber; and (4) the dynamics of a large magma body undergoing fractionation toward ferrobasalt. The Leg 91 data presented here do not add significantly to this debate, because comagmatic relationships cannot be unequivocally determined, so the case for open-system fractionation must rest.

Nonetheless, an overall conclusion is that it is possible to relate, at least on a semiquantitative basis, Units $595 \mathrm{~B}-1,2$, and 3 by plagioclase, clinopyroxene, and minor olivine fractionation. The ratios of highly incompatible elements (e.g., $\mathrm{La} / \mathrm{Ta}, \mathrm{La} / \mathrm{Sm}, \mathrm{Th} / \mathrm{Hf}$ ) remain constant throughout the analyzed interval indicating derivation from a common parental magma and, probably, compositionally identical mantle sources, at least with respect to these elements (cf. Bougault et al., 1980; Tarney et al., 1980).

\section{Comparison with Young Pacific Crust}

The Leg 91 basalts provide an important monitor of Pacific crustal and mantle evolution since Mesozoic, possibly Jurassic, times. No other pre-Cretaceous oceanic crust sections are presently available except for those from the Nauru Basin. However, the Nauru Basin is underlain by thickened crust that, at least in the drilled sections, probably represents off-axis oceanic floor basalt (Larson, Schlanger, et al., 1981; Moberly, Schlanger, et al., in press). Two main comparisons may be drawn between the Leg 91 basalts and younger (post-Mesozoic) Pacific crust; (1) the main compositional components of the crustal sections, and (2) the compositions of their mantle sources.

Four areas of drilled Pacific basement provide comparisons with the Leg 91 successions: the Nazca Plate (Leg 34: Yeats, Hart, et al., 1976); the Galapagos Spreading Center and EPR $9^{\circ} \mathrm{N}$ (Leg 54: Rosendahl, Hekinian, et al., 1980); EPR $23^{\circ} \mathrm{N}$ (Leg 65: Lewis, Robinson, et al., 1983); and the Costa Rica Rift (Leg 69: Cann, Langseth, et al., 1983). The majority of basement holes drilled during these legs, with the exception of the Costa 
Table 3 (continued).

\begin{tabular}{|c|c|c|c|c|c|c|c|c|}
\hline \multicolumn{8}{|c|}{ Hole 595B } & \multirow{2}{*}{$\frac{\text { Hole } 596}{9-1,81-83}$} \\
\hline $3-1,131-134$ & $4-1,12-15$ & $5-1,115-120$ & $6-3,41-45$ & $7-1,21-24$ & $7-1,123-128$ & $7-2,80-82$ & $7-3,79-83$ & \\
\hline 2 & 2 & 2 & 2 & 2 & 3 & 3 & 3 & \\
\hline 3.08 & 2.86 & - & - & 2.70 & 1.92 & 1.86 & - & 1.49 \\
\hline 0.63 & 0.57 & - & - & 0.99 & 0.59 & 0.71 & - & 0.64 \\
\hline 0.16 & 0.20 & - & - & 0.41 & 0.14 & 0.15 & - & 0.13 \\
\hline 41 & 50 & 45 & 43 & 56 & 80 & 61 & 67 & 46 \\
\hline 52 & 58 & 50 & 55 & 96 & 196 & 183 & 184 & 371 \\
\hline 12 & 7 & 13 & 10 & 8 & 11 & 12 & 9 & 10 \\
\hline 115 & 115 & 118 & 110 & 116 & 109 & 110 & 113 & 144 \\
\hline 36 & 44 & 44 & 36 & 42 & 23 & 26 & 25 & 33 \\
\hline 58 & 58 & 56 & 55 & 56 & 39 & 38 & 38 & 27 \\
\hline 157 & 157 & 163 & 156 & 131 & 103 & 102 & 102 & 82 \\
\hline 5 & 5 & 6 & 5 & 5 & 3 & 4 & 4 & 2 \\
\hline 31 & 31 & 27 & 31 & 26 & 24 & 25 & 25 & 41 \\
\hline 118 & 109 & - & - & 124 & 112 & 110 & - & 109 \\
\hline 2.7 & 2.7 & 2.9 & 2.8 & 2.4 & 2.6 & 2.7 & 2.7 & 3.0 \\
\hline 4.4 & 5.6 & - & - & 13.7 & 5.9 & 6.5 & - & 6.9 \\
\hline
\end{tabular}

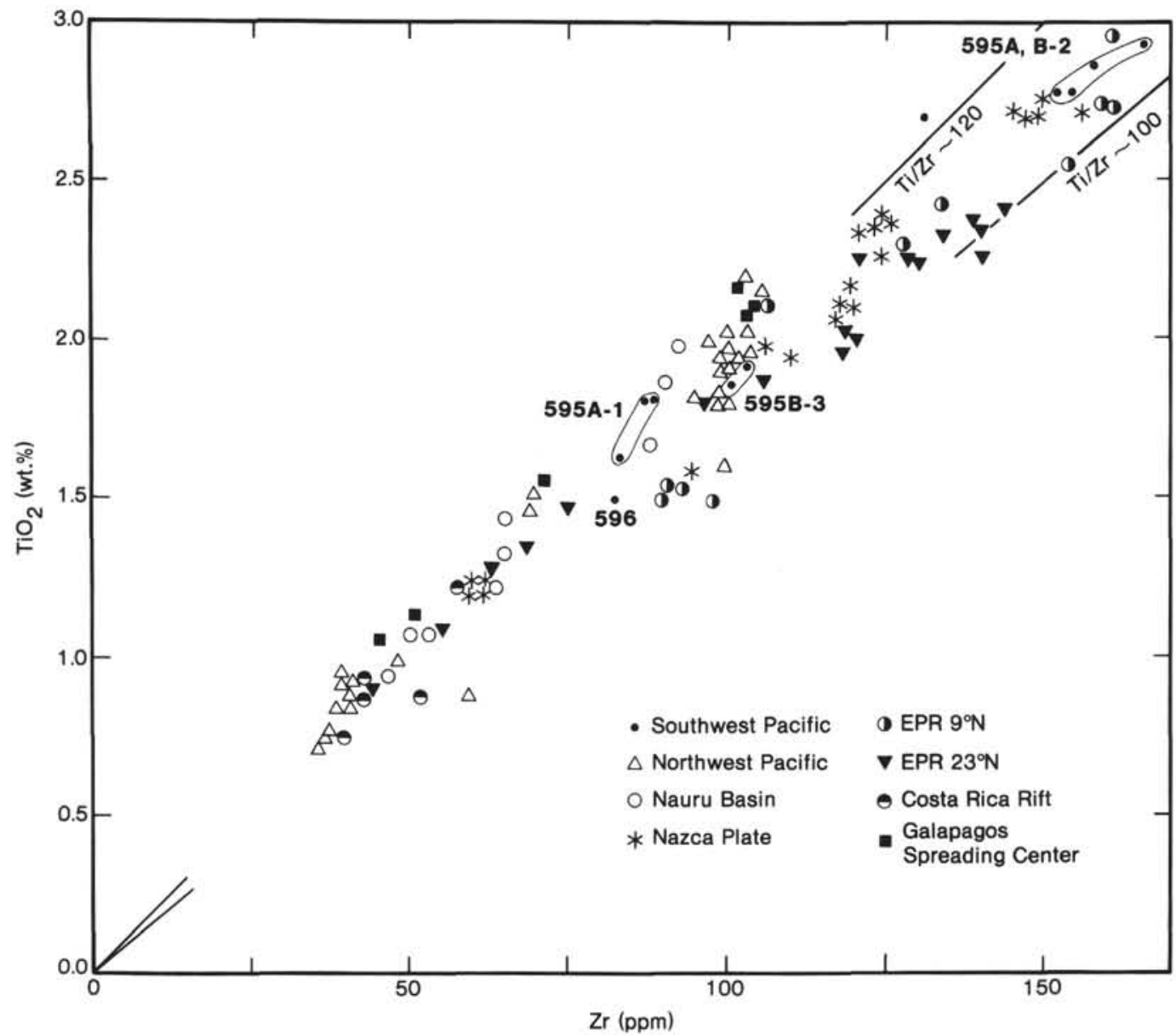

Figure 3. $\mathrm{TiO}_{2}$ versus $\mathrm{Zr}$ for Leg 91 and selected Pacific basalts. Note the essentially consistent $\mathrm{TiO}_{2} / \mathrm{Zr}$ ratio. Data sources-Leg 91: Tables 2 and 3; Nauru Basin (Legs 61 and 89): Saunders (in press); Galapagos Spreading Center and EPR $9^{\circ} \mathrm{N}$ (Leg 54): Saunders (unpublished data, and Table 5); EPR $23^{\circ} \mathrm{N}$ (Leg 65): Saunders (1983); Nazca Plate: Saunders (unpublished data, and Table 5); Costa Rica Rift: Saunders (unpublished data).

Rica leg, recovered successions of altered tholeiites and ferrobasalts, representative analyses of which are given in Table 5 .

The high frequency of ferrobasalts in the Pacific basement-compared with the Atlantic-has been noted by several workers (Bass, 1971; Scheidegger, 1973; Melson et al., 1976; Natland, 1978, 1980). In general, ferrobasalts are associated with fast and intermediate-rate spreading ridges, implying a causative link with the processes of crustal generation. Of particular importance in this 


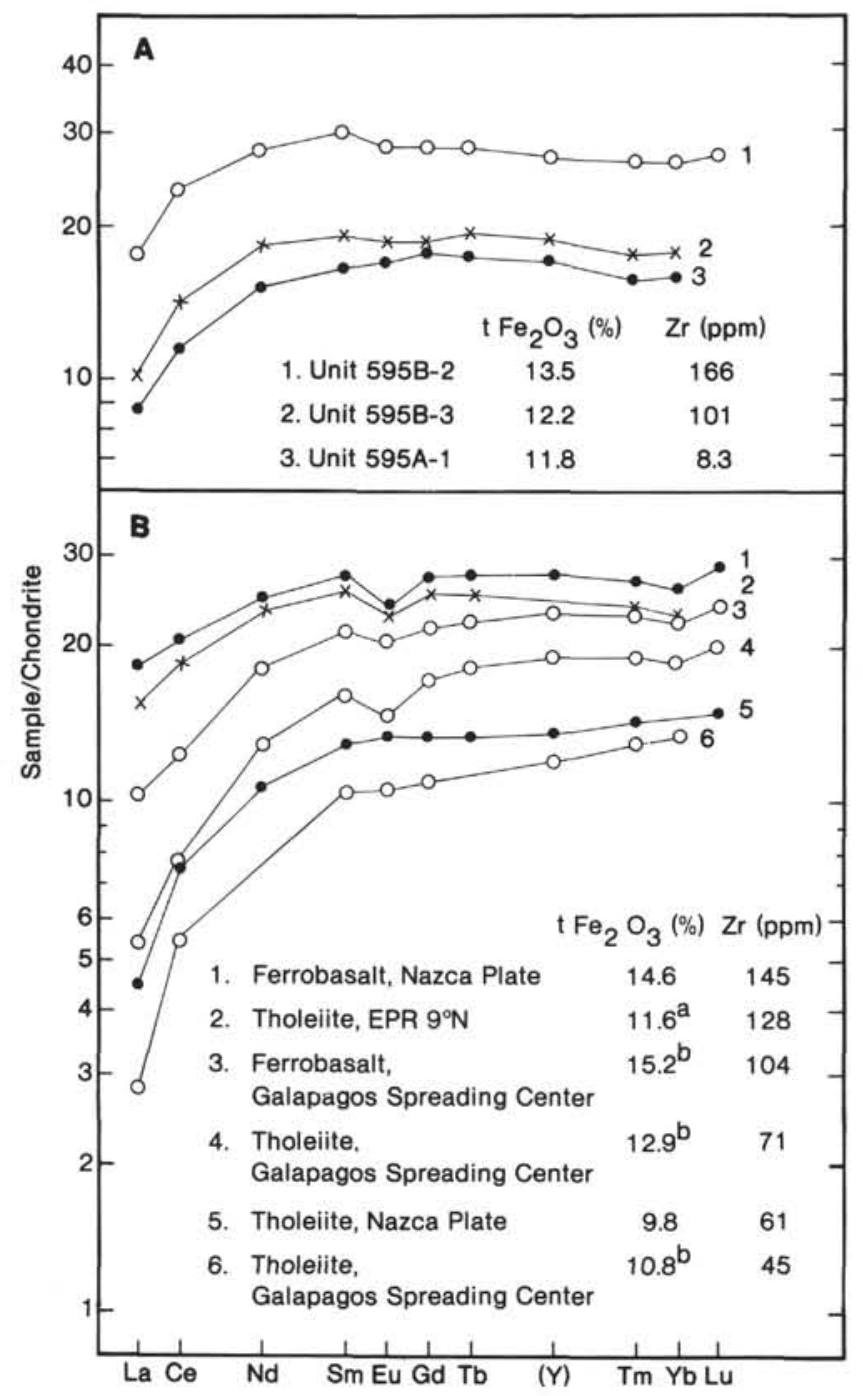

Figure 4. Chondrite-normalized REE data. A. Leg 91 basalts. B. Representative tholeiites and tholeiitic ferrobasalts from the eastern Pacific. Data are taken from Table 5 for the following samples: (1) 421-14-1, 144-146 cm; (2) 420-14-1, 40-44 cm; (3) 424-6-1, 75-77 $\mathrm{cm}$; (4) 425-7-1, 52-54 cm; (5) 319A-1-1, 130-133 cm; (6) 425-9-1, $50 \mathrm{~cm}$. $\mathrm{t} \mathrm{Fe} \mathrm{F}_{2} \mathrm{O}_{3}=$ total iron as $\mathrm{Fe}_{2} \mathrm{O}_{3}$; (a) $\mathrm{t} \mathrm{Fe}_{2} \mathrm{O}_{3}$ from Humphris et al. (1980) (adjacent sample); (b) $\mathrm{t} \mathrm{Fe}_{2} \mathrm{O}_{3}$ from Mattey and Muir (1980) (adjacent sample).

respect is the location, shape, and longevity of the subridge magma chamber. Natland (1980), for example, has proposed that the shape and depth of the chamber are the factors governing ferrobasalt formation. Where it is shallow with a broad, flat top and a broad zone of magma injection, the chamber may be able to migrate laterally from place to place (van Andel and Ballard, 1979). This could promote isolation of magma pockets in which ferrobasalts can form.

It is reasonable to suggest that the magma chamber broadens and flattens where magma supply rates are high, hence the general but not unique correlation between ferrobasalts and high spreading rates. Two minor objections may be raised against this model, however, although neither disproves the overall thesis. First, separation and closed-system fractionation of small, discrete magma batches does not explain alone the discrepancies between

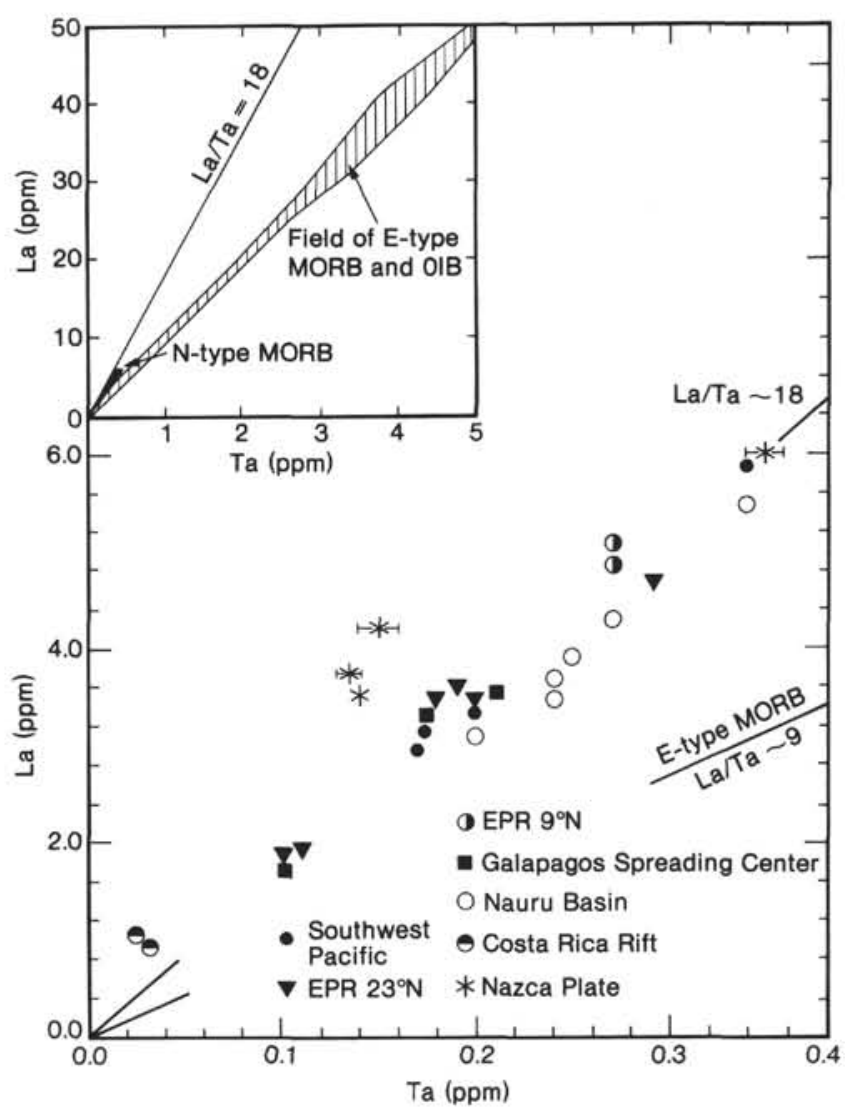

Figure 5. La versus Ta for Leg 91 and Pacific basalts. Data sources indicated in Figure 3. Ratio for E-type MORB from Bougault et al. (1980), Tarney et al. (1980), and Wood et al. (1979). Inset: compressed scale to illustrate the range of abundances observed in E-type MORB and ocean island basalts (OIB), as distinct from the very restricted $\mathrm{La}$ and $\mathrm{Ta}$ abundances in N-type MORB. Range of OIB values from summary in Saunders (1984).

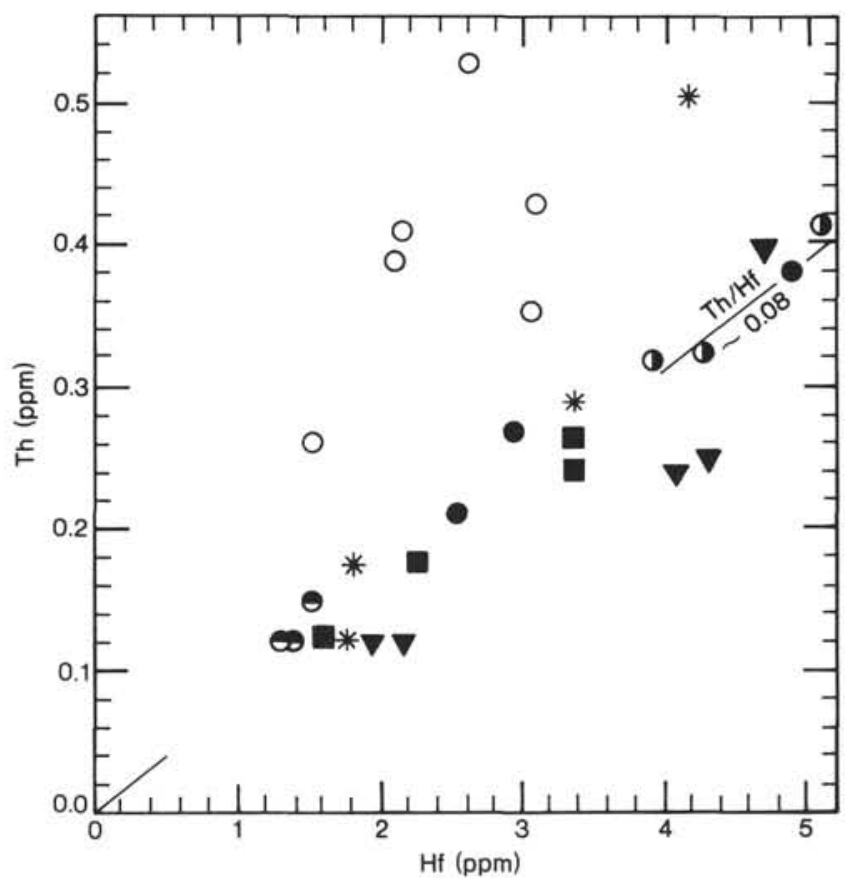

Figure 6. Th versus Hf for Leg 91 and Pacific basalts. Data sources given in Figure 3, symbols are the same as those used in Figure 5. 
Table 4. Neutron activation analyses, Leg 91 basalts.

\begin{tabular}{|c|c|c|c|}
\hline & Hole 595A & Hole 595B & Hole 595B \\
\hline & $10-1,103-109^{\mathrm{a}}$ & $\overline{2-1,112-116}$ & $7-2,80-82$ \\
\hline & $1^{b}$ & 2 & 3 \\
\hline $\mathrm{La}$ & 2.9 & 5.9 & 3.3 \\
\hline $\mathrm{Ce}$ & 10.3 & 20.5 & 12.7 \\
\hline Nd & 9.5 & 18.1 & 11.4 \\
\hline $\mathrm{Sm}$ & 3.3 & 6.1 & 3.9 \\
\hline $\mathrm{Eu}$ & 1.30 & 2.17 & 1.44 \\
\hline Gd & 5.0 & 7.7 & 5.13 \\
\hline $\mathrm{Tb}$ & 0.89 & 1.49 & 0.99 \\
\hline $\mathrm{Tm}$ & 0.53 & 0.89 & 0.59 \\
\hline $\mathrm{Yb}$ & 3.45 & 5.79 & 3.82 \\
\hline Lu & - & 0.92 & - \\
\hline $\mathrm{Ta}$ & 0.17 & 0.34 & 0.20 \\
\hline Th & 0.21 & 0.38 & 0.27 \\
\hline $\mathrm{Hf}$ & 2.55 & 4.92 & 2.95 \\
\hline $\mathrm{La} / \mathrm{Ta}$ & 17.1 & 17.4 & 16.5 \\
\hline $\mathrm{Th} / \mathrm{Hf}$ & 0.08 & 0.07 & 0.09 \\
\hline $\mathrm{La} / \mathrm{Th}$ & 13.8 & 15.5 & 12.2 \\
\hline $\mathrm{La}_{\mathrm{n}} / \mathrm{Yb}_{\mathrm{n}}$ & 0.57 & 0.68 & 0.58 \\
\hline $\mathrm{La}_{\mathrm{n}} / \mathrm{Sm}_{\mathrm{n}}$ & 0.55 & 0.59 & 0.53 \\
\hline
\end{tabular}

Note: Trace elements in ppm. $\mathrm{La}_{\mathrm{n}} / \mathrm{Yb}_{\mathrm{n}}=$ chondrite-normalized $\mathrm{La} / \mathrm{Yb}$ ratio. - = not analyzed

a Core-Section (interval in $\mathrm{cm}$ ).

b Unit no.

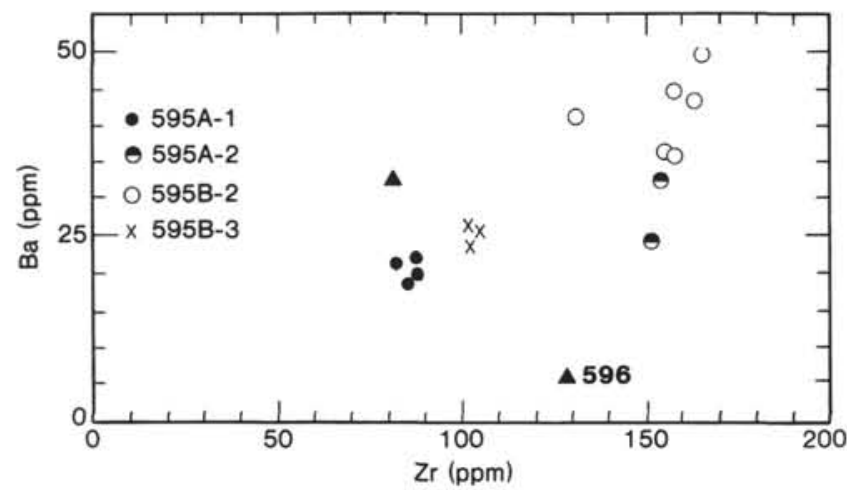

Figure 7. Ba versus $\mathrm{Zr}$ for Leg 91 and Pacific basalts. Data sources given in Figure 3.

major and trace element modeling reported earlier. This problem could presumably be overcome if the subchambers underwent open-system fractionation. Secondly, it could be predicted from the model that ferrobasalts would be found more frequently in an off-axis setting, because it is likely that the isolated, distal portions of the main magma chamber would be located farthest from the ridge axis. Indeed, it is interesting to speculate that this may be the case at some ridge segments, for example, EPR $23^{\circ} \mathrm{N}$. Here, drilling during Leg 65 penetrated sheet flows apparently erupted in fault-bounded basins, possibly erupted in a slightly off-axis setting (Lewis, 1979; Lewis, Robinson, et al., 1983). The "true" axial activity appears to be represented by topographic highs that could not be drilled, because of the lack of sediment cover. Hence, there is a possibility of sampling bias during drilling, but it is noteworthy that iron-rich tholeiites form a major part of the fault-bounded sheet flows.
Notwithstanding these arguments, there is a general consensus that ferrobasalts are associated with fast-spreading ridges and are a common feature of post-Mesozoic Pacific crust. Therefore, it is of interest to report the occurrence of ferrobasalts in crust of Jurassic age, implying crustal accretion processes petrologically similar to those operating at the present-day and Cenozoic EPR.

This comparison can be extended to include the minor and trace element geochemistry.

1. The $\mathrm{TiO}_{2}$ abundances at given total iron contents are virtually identical to those observed in present-day EPR basalts, but higher than in basalts from the Galapagos Spreading Center (cf. Natland, 1980).

2. $\mathrm{Ti} / \mathrm{Zr}$ ratios are within the range of Cenozoic $\mathrm{Pa}$ cific N-type MORB (i.e., most Pacific Ocean basalts) (Table 5, Fig. 3).

3. Similarly, the $\mathrm{Zr} / \mathrm{Nb}, \mathrm{La} / \mathrm{Yb}$, and $\mathrm{Th} / \mathrm{Hf}$ ratios are identical to those observed in younger EPR, Galapagos Spreading Center, and MAR N-type MORB (Fig. 4, $6)$.

4. More important, however, is the observation that highly incompatible ratios such as $\mathrm{La} / \mathrm{Ta}$ and $\mathrm{La} / \mathrm{Th}$ are also identical to those in younger Pacific basalt (Fig. 5, Table 5). These ratios are thought to mirror source values (e.g., Bougault et al., 1980), assuming that MORB represent at least $5 \%$ melting of mantle material, and therefore it is apparent that the source for Pacific N-type MORB has retained constant $\mathrm{La} / \mathrm{Ta}$ and $\mathrm{La} / \mathrm{Th}$ ratios since at least Mesozoic times. A similar line of reasoning can probably be extended to $\mathrm{Th} / \mathrm{Hf}, \mathrm{La} / \mathrm{Yb}$, and $\mathrm{Zr} / \mathrm{Nb}$ ratios, although these ratios are more susceptible to the effects of fractionation and may not truly reflect source values.

The data thus confirm Schilling's (1975) suggestion that the N-type MORB reservoir is of considerable extent in both spatial and temporal dimensions and was clearly being tapped during ridge activity in Mesozoic times. Off-axis activity, such as that preserved in the Nauru Basin, has a different chemical signature (higher $\mathrm{La}$ / $\mathrm{Yb}, \mathrm{Th} / \mathrm{Hf}$, and $\mathrm{Ta} / \mathrm{Zr}$ ratios than in N-type MORB: Saunders, in press, and Figs. 4, 6) and would appear to have been derived from a chemically distinct source, transitional between the N-type MORB source and an ocean island basalt source. Despite all the variables that affect basalt production and may subtly alter trace element ratios, much of the Pacific crust has retained a consistent primary chemical signature.

\section{CONCLUSIONS}

1. Drilling in the southwest Pacific during Leg 91 resulted in recovery of a basaltic core from three holes: 595A, 595B, and 596.

2. Three distinct lithological units, two of tholeiitic basalt and one of ferrobasalt, can be recognized in the succession from Hole 595B. These uppermost units can be correlated with the succession from Hole 595A.

3. All of the basalts are evolved tholeiites, but Unit 595B-2 is a highly evolved ferrobasalt with $13-15 \%$ total $\mathrm{Fe}_{2} \mathrm{O}_{3}$. The succession, therefore, resembles other recovered cores from elsewhere in the Pacific Basin and which are thought typical of fast-spreading ocean crust. 
Table 5. Analyses of representative tholeiites and tholeiitic ferrobasalts, Pacific Ocean.

\begin{tabular}{|c|c|c|c|c|c|c|c|c|c|c|c|c|}
\hline & \multicolumn{3}{|c|}{ Leg 91} & \multicolumn{2}{|c|}{ Nazca Plate } & \multicolumn{2}{|c|}{$\begin{array}{c}\text { Galapagos } \\
\text { Spreading } \\
\text { Center }\end{array}$} & \multicolumn{2}{|c|}{ EPR $23^{\circ} \mathrm{N}$} & \multirow{2}{*}{$\frac{E P R 9^{\circ} \mathrm{N}}{10}$} & \multirow{2}{*}{$\frac{\text { Nauru Basin }}{11}$} & \multirow{2}{*}{$\begin{array}{c}\begin{array}{c}\text { Northwest } \\
\text { Pacific }\end{array} \\
12\end{array}$} \\
\hline & 1 & 2 & 3 & 4 & 5 & 6 & 7 & 8 & 9 & & & \\
\hline \multicolumn{13}{|l|}{ Major oxides } \\
\hline $\mathrm{SiO}_{2}$ & 50.1 & 49.8 & 48.9 & 50.5 & 4.1 & 51.5 & 50.2 & 49.5 & 48.4 & 50.7 & 49.0 & 50.2 \\
\hline $\mathrm{TiO}_{2}$ & 1.63 & 1.86 & 2.94 & 1.24 & 2.73 & 0.99 & 1.89 & 1.24 & 2.41 & 1.95 & 1.99 & 2.20 \\
\hline $\mathrm{Al}_{2} \mathrm{O}_{3}$ & 14.5 & 14.5 & 14.8 & 14.8 & 12.6 & 14.3 & 12.7 & 16.0 & 14.5 & 14.1 & 14.6 & 16.30 \\
\hline $\mathrm{tFe}_{2} \mathrm{O}_{3}$ & 11.8 & 12.18 & 13.5 & 9.82 & 14.59 & 10.78 & 15.16 & 9.68 & 13.67 & 12.83 & 13.76 & 10.35 \\
\hline $\mathrm{MnO}$ & 0.18 & 0.24 & 0.15 & 0.18 & 0.23 & 0.17 & 0.20 & 0.16 & 0.20 & 0.20 & 0.21 & 0.16 \\
\hline $\mathrm{MgO}$ & 6.83 & 6.64 & 5.92 & 7.77 & 6.16 & 7.28 & 5.83 & 7.6 & 6.6 & 6.71 & 6.83 & 7.98 \\
\hline $\mathrm{CaO}$ & 11.80 & 10.80 & 7.70 & 12.54 & 10.95 & 12.47 & 10.49 & 12.17 & 11.50 & 11.11 & 10.87 & 9.79 \\
\hline $\mathrm{Na}_{2} \mathrm{O}$ & 2.62 & 2.89 & 3.31 & 2.41 & 2.40 & 2.04 & 2.32 & 2.60 & 2.64 & 2.85 & 2.62 & 2.95 \\
\hline $\mathrm{K}_{2} \mathrm{O}$ & 0.48 & 0.71 & 0.92 & 0.14 & 0.20 & 0.01 & 0.03 & 0.05 & 0.12 & 0.32 & 0.10 & 0.10 \\
\hline $\mathrm{P}_{2} \mathrm{O}_{5}$ & 0.11 & 0.15 & 0.20 & 0.09 & 0.20 & 0.08 & 0.21 & 0.12 & 0.20 & 0.20 & 0.17 & 0.16 \\
\hline Mg No. & 56.5 & 55.1 & 49.6 & 64.1 & 48.7 & 60.4 & 46.4 & 64.0 & 52.1 & 53.8 & 52.7 & 63.5 \\
\hline \multicolumn{13}{|c|}{ Trace elements (ppm) } \\
\hline $\mathrm{Ni}$ & 78 & 61 & 46 & 153 & 57 & 84 & 50 & 53 & 61 & 110 & 103 & 83 \\
\hline $\mathrm{Cr}$ & 204 & 183 & 50 & 277 & 128 & 350 & 80 & 306 & 140 & 172 & 164 & 257 \\
\hline $\mathbf{R b}$ & 3 & 12 & 16 & 2 & 3 & $<1$ & $<1$ & $<1$ & $<1$ & 2 & 1 & $<1$ \\
\hline $\mathrm{Sr}$ & 107 & 110 & 118 & 101 & 92 & 52 & 67 & 115 & 109 & 137 & 125 & 119 \\
\hline $\mathrm{Ba}$ & 19 & 26 & 49 & 7 & 38 & 23 & 22 & 15 & 37 & 38 & 25 & \\
\hline $\mathbf{Y}$ & 35 & 38 & 54 & 28 & 53 & 25 & 48 & 27 & 49 & 46 & 40 & 36 \\
\hline $\mathrm{Zr}$ & 86 & 101 & 166 & 61 & 145 & 45 & 104 & 65 & 144 & 128 & 90 & 103 \\
\hline $\mathrm{Nb}$ & 3 & 4 & 6 & 1 & 7 & 2 & 4 & 2 & 4 & 5 & 7 & 4 \\
\hline $\mathrm{Ta}$ & 0.17 & 0.2 & 0.34 & 0.07 & 0.35 & 0.07 & 0.17 & 0.10 & 0.29 & 0.27 & 0.34 & - \\
\hline Th & 0.21 & 0.27 & 0.38 & 0.12 & 0.51 & 0.12 & 0.26 & 0.12 & 0.40 & 0.32 & 0.53 & - \\
\hline $\mathrm{Hf}$ & 2.55 & 2.95 & 4.92 & 1.78 & 4.17 & 1.64 & 3.37 & 2.22 & 4.76 & 3.86 & 2.6 & - \\
\hline $\mathrm{La}$ & 2.9 & 3.3 & 5.9 & 1.7 & 6.0 & 0.9 & 3.3 & 01.9 & 4.7 & 5.0 & 5.5 & - \\
\hline $\mathrm{Ce}$ & 10.3 & 12.7 & 20.5 & 6.0 & 17.4 & 4.8 & 10.8 & 8.7 & 18.1 & 16.2 & 13.9 & - \\
\hline $\mathrm{Nd}$ & 9.5 & 11.4 & 18.1 & 6.4 & 15.6 & 6.5 & 11.9 & 8.1 & 18.1 & 15.2 & 11.0 & - \\
\hline $\mathrm{Sm}$ & 3.3 & 3.9 & 6.1 & 2.7 & 5.6 & 2.1 & 4.4 & 2.9 & 8.0 & 5.1 & 3.5 & - \\
\hline Eu & 1.30 & 1.44 & 2.17 & 1.03 & 1.81 & 0.83 & 1.54 & 1.30 & 2.19 & 1.80 & 1.28 & - \\
\hline $\mathrm{Tb}$ & 0.89 & 0.99 & 1.49 & 0.70 & 1.41 & 0.65 & 1.19 & 0.75 & 1.53 & 1.29 & 0.87 & - \\
\hline $\mathrm{Tm}$ & 0.53 & 0.59 & 0.89 & 0.49 & 0.90 & 0.45 & 0.80 & 0.50 & 0.96 & 0.77 & 0.59 & - \\
\hline $\mathrm{Yb}$ & 3.45 & 3.82 & 5.79 & 2.78 & 5.45 & 2.99 & 5.04 & 3.14 & 6.09 & 4.87 & 3.40 & - \\
\hline \multicolumn{13}{|l|}{ Ratios } \\
\hline $\mathrm{La} / \mathrm{Ta}$ & 17 & 17 & 17 & 24 & 17 & 13 & 19 & 19 & 16 & 19 & 16 & \\
\hline $\mathrm{Th} / \mathrm{Hf}$ & 008 & 0.09 & 0.07 & 0.07 & 0.12 & 0.07 & 0.08 & 0.05 & 0.08 & 0.08 & 0.20 & \\
\hline $\mathrm{La} / \mathrm{Th}$ & 13.8 & 12.2 & 15.5 & 14.2 & 11.8 & 7.5 & 12.7 & 15.8 & 11.8 & 15.6 & 10.4 & \\
\hline $\mathrm{La}_{\mathrm{n}} / \mathrm{Yb} \mathrm{b}_{\mathrm{n}}$ & 0.57 & 0.58 & 0.68 & 0.41 & 0.74 & 0.20 & 0.44 & 0.41 & 0.52 & 0.69 & 1.1 & \\
\hline $\mathrm{La}_{\mathrm{n}} / \mathrm{Sm}_{\mathrm{n}}$ & 0.55 & 0.53 & 0.59 & 0.39 & 0.66 & 0.27 & 0.46 & 0.41 & 0.48 & 0.61 & 1.0 & \\
\hline $\mathrm{Zr} / \mathrm{Nb}$ & 29 & 25 & 28 & (61) & 21 & 23 & 26 & 33 & 36 & 26 & 13 & \\
\hline $\mathrm{Zr} / \mathrm{Ta}$ & 506 & 505 & 488 & 871 & 414 & 643 & 612 & 650 & 497 & 474 & 265 & \\
\hline $\mathrm{Ti} / \mathrm{Zr}$ & 114 & 110 & 106 & 122 & 113 & 132 & 109 & 114 & 100 & 91 & 133 & \\
\hline $\mathrm{Nb} / \mathrm{Ta}$ & 18 & 20 & 18 & (14) & 20 & (29) & 24 & (20) & 14 & 19 & 21 & \\
\hline $\mathrm{Zr} / \mathrm{Hf}$ & 34 & 34 & 34 & 34 & 35 & 27 & 31 & 29 & 30 & 33 & 35 & \\
\hline
\end{tabular}

Note: (1) Major oxides, 595A-10-4, 76-80 cm; trace elements, 595A-10-1, 103-107 cm; (2) 595B-7-2, 80-82 cm; (3) 595B-2-1, 112-116 cm; (4) 319A-1-1, $130-133 \mathrm{~cm}$ (unpublished data); (5) 321-14-1, 144-146 cm (Saunders, unpublished data); (6) major oxides, 425-9-3, piece 9 (Mattey and Muir, 1980); trace elements, 425-9-1, 50-52 cm (Saunders, unpublished data); (7) major oxides, 424-6-1, piece 10c (Mattey and Muir, 1980); trace elements, 424-6-1, 75-78 cm (Saunders, unpublished data); (8) 483-15-2, 1-3 cm; (9) 483-24-1, 96-98 cm (8 and 9 from Saunders, 1983); (10) major oxides, 420-14-1, piece 8 (Humphris et al., 1980); trace elements, 420-14-1, 40-44 cm (Saunders, unpublished data); (11) 462A-23-4, 74-76 cm (Saunders, in press); (12) 581B-3-3, 6-8 cm (Saunders, this volume). $-=$ not analyzed.

4. It is possible to relate, on a qualitative basis, the basalts from Units 1,2 , and 3 by open-system fractionation of pyroxene, plagioclase, and minor olivine.

5. All of the recovered basalts are light-REE depleted tholeiites with trace element ratios identical to N-type MORB from elsewhere in the Pacific (e.g., $\mathrm{La} / \mathrm{Ta} \sim 18$; $\mathrm{Th} / \mathrm{Hf} \sim 0.08 ; \mathrm{Ti} / \mathrm{Zr} \sim 110$.

6 . These results imply that the reservoir for ridgegenerated Pacific crust has not significantly evolved since Mesozoic times.

\section{ACKNOWLEDGMENTS}

The manuscript was improved by the comments of Rodey Batiza. I would like to thank Giz Marriner and Brian Nimblette for assistance with the XRF and INAA analysis at Bedford College, and Sue Button for the artwork. I thank Jim Natland for providing the glass analyses and providing additional comments on the text.

\section{REFERENCES}

Bass, M. N., 1971. Variable abyssal basalt populations and their relation to sea-floor spreading rates. Earth Planet. Sci. Lett., 11:1822.

Bougault, H., Jordon, J.-L., and Treuil, M., 1980. The primordial chondritic nature and large-scale heterogeneities in the mantle: evidence from high and low partition coefficient elements in oceanic basalts. Phil. Trans. R. Soc. London, 297:203-213.

Cann, J. R., Langseth, M. G., et al., 1983. Init. Repts. DSDP, 69: Washington (U.S. Govt. Printing Office).

Fujii, T., and Bougault, H., 1983. Melting relations of a magnesian abyssal tholeiite and the origin of MORBs. Earth Planet. Sci. Lett., 62:283-295. 
Hart, S. R., 1971. K, Rb, Cs, Sr and Ba contents and Sr isotope ratios of ocean floor basalts. Phil. Trans. R. Soc. London, A268:573-578.

Hart, S. R., Erlank, A. J., and Kable, E. J. D., 1974. Seafloor basalt alteration: some chemical and strontium isotopic effects. Contrib. Mineral. Petrol., 44:219-230.

Humphris, S. E., 1984. The mobility of rare earth elements in the crust. In Henderson, P. (Ed.), Rare Earth Element Geochemistry: New York (Elsevier), pp. 317-342.

Humphris, S. E., Thompson, R. N., Gibson, I. L., and Marriner, G. F., 1980. Comparison of geochemistry of basalts from the East $\mathrm{Pa}$ cific Rise, OCP Ridge, and Siqueiros Fracture Zone, Deep Sea Drilling Project Leg 54. In Rosendahl, B. R., Hekinian, R., et al., Init. Repts. DSDP, 54: Washington (U.S. Govt. Printing Office), 635-649.

Irving, A. J., 1978. A review of experimental studies of crystal/liquid trace element partitioning. Geochim. Cosmochim. Acta, 42:743770.

Kay, R. W., Hubbard, N. J., and Gast, P. W., 1970. Chemical characteristics of oceanic ridge volcanic rocks. J. Geophy. Res., 75:15851613.

Larson, R. L., Schlanger, S. O., et al., 1981. Init. Repts. DSDP, 61: Washington (U.S. Govt. Printing Office).

Lewis, B. T. R., 1979. Periodicities in volcanism and longitudinal magma flow in the East Pacific Rise at $23^{\circ} \mathrm{N}$. Geophys. Res. Lett., 6: 753-756.

Lewis, B. T. R., Robinson, P., et al., 1983. Init. Repts. DSDP, 65: Washington (U.S. Govt. Printing Office).

Ludden, J. N., and Thompson, G., 1978. Behavior of rare earth elements during submarine weathering of tholeiitic basalts. Nature, 274:147-149.

Marsh, N. G., Tarney, J., and Hendry, G. L., 1983. Trace element geochemistry of basalts from Hole 504B, Panama Basin, Deep Sea Drilling Project Legs 69 and 70. In Cann, J. R., Langseth, M. G., et al., Init. Repts. DSDP, 69: Washington (U.S. Govt. Printing Office), 747-763.

Mattey, D. P., and Muir, I. D., 1980. Geochemistry and mineralogy of basalts from the Galapagos Spreading Center, Deep Sea Drilling Project Leg 54. In Rosendahl, B. R., Hekinian, R., et al., Init. Repts. DSDP, 54: Washington (U.S. Govt. Printing Office), 755771.

Melson, W. G., Vallier, T. L., Byerly, G. R., and Nelen, J. A., 1976. Chemical diversity of abyssal volcanic glasses erupted along Pacific, Atlantic and Indian Ocean sea-floor spreading centers. Geophys. Monogr., 19: Washington (Am. Geophys. Un.), pp. 351368.

Moberly, R., Schlanger, S. O., et al., in press. Init. Repts. DSDP, 89: Washington (U.S. Govt. Printing Office).

Natland, J. H., 1978. Comparison of the chemical and magnetic stratigraphy of DSDP Sites 323 and 395. In Melson, W. G., Rabinowitz, P. D., et al., Init. Repts. DSDP, 45: Washington (U.S. Govt. Printing Office), 657-677.

1980. Effect of axial magma chambers beneath spreading centers on compositions of basaltic rocks. In Rosendahl, B. R., Hekinian, R., et al., Init. Repts. DSDP, 54: Washington (U.S. Govt. Printing Office), 833-850.

Natland, J. H., Adamson, A., Laverne, C., Melson, W. G., and O'Hearn, T., 1983. A compositionally nearly steady-state magma chamber at the Costa Rica Rift: Evidence from basalt glass and mineral data, Deep Sea Drilling Project Sites 501, 504, and 505. In Cann, J. R., Langseth, M. G., Honnorez, J., von Herzen, R. P., White, S. M., et al., Init. Repts. DSDP, 69: Washington (U.S. Govt. Printing Office), 811-858.

O'Hara, M. J., 1977. The geochemistry of lavas erupted from a mayma chamber undergoing fractional crystallization with periodic addition and intermingling of more primitive magma. Nature, 266: 503-507.

O'Hara, M. J., and Mathews, R. E., 1981. Geochemical evolution in an advancing, periodically replenished, periodically tapped, continuously fractionated magma chamber. J. Geol. Soc. London, 138: 237-278.

Rhodes, J. M., Blanchard, D. P., Rodgers, K. V., Jacobs, J. W., and Brannon, J. C., 1976. Petrology and chemistry of basalts from the Nazca Plate: Part 2-Major and trace element chemistry. In Yeats,
R. S., Hart, S. R., et al., Init. Repts. DSDP, 34: Washington (U.S. Govt. Printing Office), 239-244.

Rosendahl, B. R., Hekinian, R., et al., 1980. Init. Repts. DSDP, 54: Washington (U.S. Govt. Printing Office).

Saunders, A. D., 1983. Geochemistry of basalts recovered from the Gulf of California during Leg 65 of the Deep Sea Drilling Project. In Lewis, B. T. R., Robinson, P. et al., Init. Repts. DSDP, 65: Washington (U.S. Govt. Printing Office), 591-621. , 1984. The rare earth element characteristics of igneous rocks from the ocean basins. In Henderson, P. (Ed.), Rare Earth Element Geochemistry: New York (Elsevier), pp. 205-236. in press. Geochemistry of basalts from the Nauru Basin, Deep Sea Drilling Project Legs 61 and 89: Implications for the origin of oceanic flood basalts. In Moberly, R., Schlanger, S. O., et al., Init. Repts. DSDP, 89: Washington (U.S. Govt. Printing Office).

Scheidegger, K. F., 1973. Temperatures and compositions of magmas ascending along mid-ocean ridges. J. Geophys. Res., 78:3340-3355.

Schilling, J.-G., 1975. Rare-earth variations across "normal segments" of the Reykjanes Ridge, $60-53^{\circ} \mathrm{N}$, Mid-Atlantic Ridge, $29^{\circ} \mathrm{S}$, and East Pacific Rise, $2-19^{\circ} \mathrm{S}$, and evidence of the composition of the underlying low velocity layer. J. Geophys. Res., 80:1459-1473.

Sun, S.-S., Nesbitt, R. W., and Sharaskin, A. Ya., 1979. Geochemical characteristics of mid-ocean ridge basalts. Earth Planet. Sci. Lett., 44:119-138.

Tarney, J., Wood, D. A., Saunders, A. D., Cann, J. R., and Varet, J., 1980. Nature of mantle heterogeneity in the North Atlantic: evidence from deep sea drilling. Phil. Trans. R. Soc. London, A297: 179-202.

Thompson, G., Bryan, W. B., Frey, F. A., Dickey, J. S., and Suen, C. J., 1976. Petrology and geochemistry of basalts from DSDP Leg 34, Nazca Plate. In Yeats, R. S., Hart, S. R., et al., Init. Repts. $D S D P, 34$ : Washington (U.S. Govt. Printing Office), 215-226.

Thompson, R. N., 1982. Magmatism of the British Tertiary Volcanic Province. Scot. J. Geol., 18:49-107.

van Andel, Tj. H., and Ballard, R. D., 1979. The Galapagos Rift at $86^{\circ} \mathrm{W}, 2$, volcanism structure and evolution of the rift valley. $J$. Geophys. Res., 84:5390-5406.

Wood, D. A., Tarney, J., Varet, J., Saunders, A. D., Bougault, H., Joron, J.-L., Treuil, M., and Cann, J. R., 1979. Geochemistry of basalts drilled in the North Atlantic by IPOD Leg 49: implications for mantle heterogeneity. Earth Planet. Sci. Lett., 42:77-97.

Yeats, R. S., Hart, S. R., et al., 1976. Init. Repts. DSDP, 34: Washington (U.S. Govt. Printing Office).

Date of Initial Receipt: 28 May 1984

Date of Acceptance: 26 March 1985

Table 6. Compositions of basaltic glasses from Site 595 .

\begin{tabular}{|c|c|c|c|}
\hline & Unit $2^{\mathrm{a}}$ & Unit $3^{b}$ & VG-2 $2^{b}$ \\
\hline $\mathrm{SiO}_{2}$ & 49.95 & 50.79 & 50.81 \\
\hline $\mathrm{Al}_{2} \mathrm{O}_{3}$ & 12.70 & 14.25 & 14.06 \\
\hline $\mathrm{FeO}$ & 14.61 & 11.54 & 11.84 \\
\hline $\mathrm{MnO}$ & 0.29 & 0.25 & 0.22 \\
\hline $\mathrm{MgO}$ & & 6.99 & 6.71 \\
\hline $\mathrm{CaO}$ & 10.11 & 11.52 & 11.12 \\
\hline $\mathrm{Na}_{2} \mathrm{O}$ & 2.7 & 2. & 2.62 \\
\hline $\mathrm{K}_{2} \mathrm{O}$ & 0.14 & 0.11 & 0.19 \\
\hline $\mathrm{TiO}_{2}$ & 2.57 & 2.59 & 2.62 \\
\hline $\mathrm{P}_{2} \mathrm{O}_{5}$ & 0.17 & 0.13 & 0.20 \\
\hline $\mathrm{NiO}$ & & & $(0.00)$ \\
\hline \multirow[t]{2}{*}{$\mathrm{Cr}_{2} \mathrm{O}_{3}$} & 0.02 & 0.03 & $(0.03)$ \\
\hline & 98.77 & 100.00 & 99.65 \\
\hline $\mathrm{Mg}^{\mathrm{c}}$ & 0.436 & 0.557 & 0.540 \\
\hline
\end{tabular}

${ }^{\text {a }}$ Averages of two analyses apiece.

b Published values (Melson et al., 1976).

$\mathrm{c}_{\mathrm{Mg}}=\mathrm{Mg} /\left(\mathrm{Mg}+\mathrm{Fe}^{2+}\right)$ where $\mathrm{Fe}^{2+} /\left(\mathrm{Fe}^{2+}+\mathrm{Fe}^{3+}\right)=0.86$ 


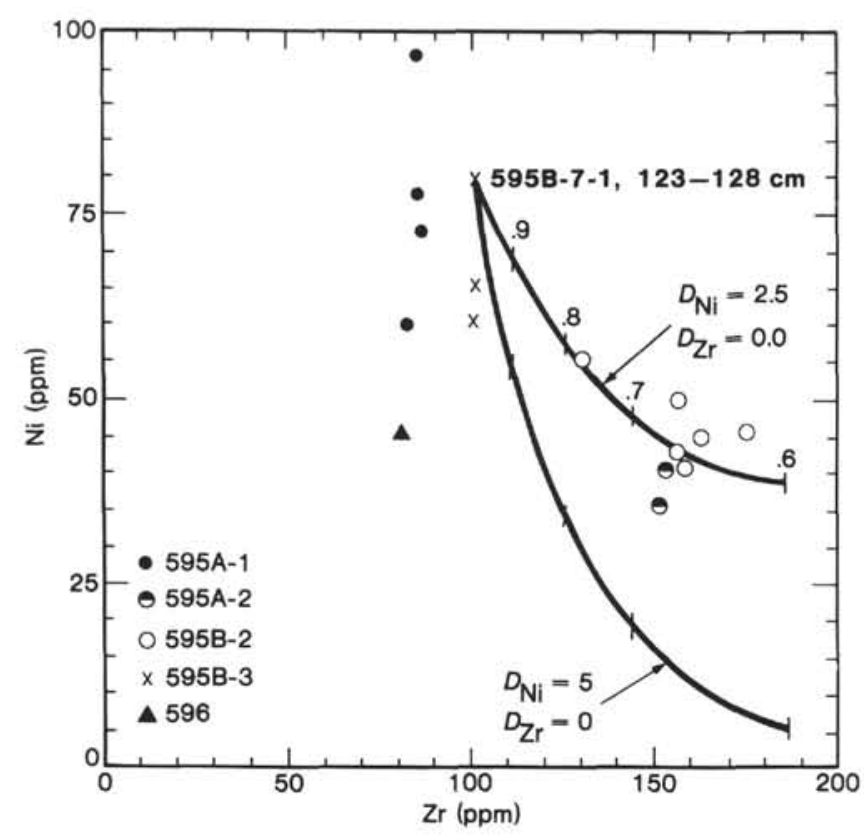

Figure 8. Ni versus $\mathrm{Zr}$ in Leg 91 basalts. Model curves assume closed system, Rayleigh surface equilibrium fractionation, and are calculated using assumed bulk distribution coefficient $D$ for $\mathrm{Zr}$ and $\mathrm{Ni}$. They essentially indicate that variation in $\mathrm{Ni}$ abundances between Units 3 and 2 can be satisfactorily explained only by fractionating minor olivine, and that intraunit variation probably involves local removal of olivine (e.g., Unit 1).

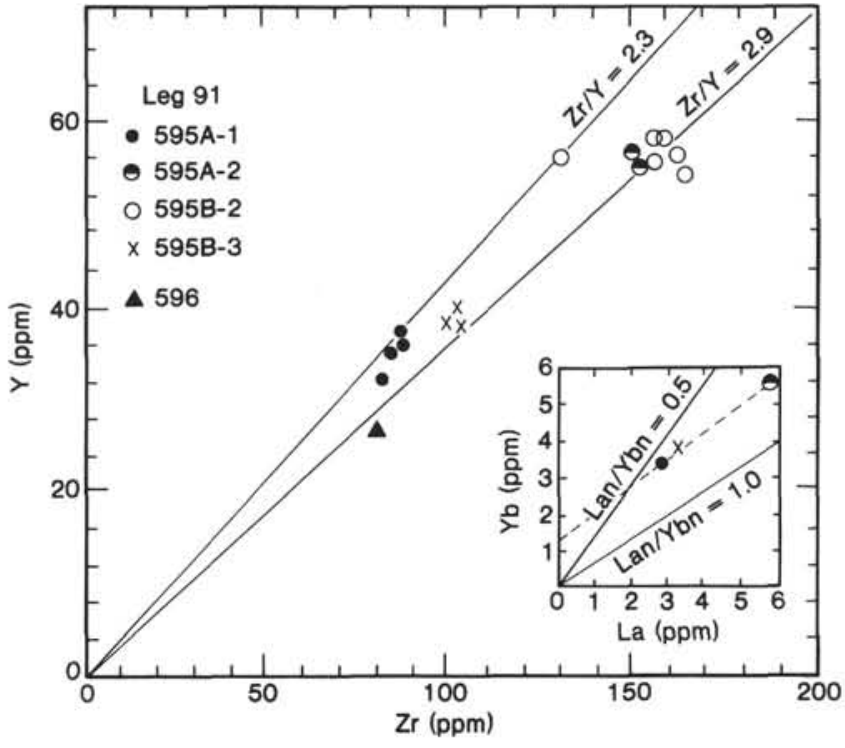

Figure 9. $\mathrm{Y}$ versus $\mathrm{Zr}$ and $\mathrm{Yb}$ versus $\mathrm{La}$ for Leg 91 basalts to illustrate the slight but significant increase in $\mathrm{Zr} / \mathrm{Y}$ and $\mathrm{La} / \mathrm{Yb}$ ratio with increasing evolution of melt. 